\title{
Pemberdayaan Guru Pondok Pesantren di Kabupaten Batang Sebagai Upaya Meningkatkan Profesionalitas Guru dalam Program Pembangunan Berkelanjutan (Sustainable Development)
}

\author{
${ }^{1}$ Devi Dwi Kurniawan, ${ }^{2} \mathrm{~S}$. Thoriqul Huda
}

\author{
Universitas Selamat Sri \\ Jalan Soekarno - Hatta, Km. 03, Kendal, Jawa Tengah, Indonesia
}

Email: ${ }^{1}$ devidwikurniawan@ gmail.com, ${ }^{2}$ s.thoriqulhudaunissbatang@gmail.com

\author{
Tersedia Online di \\ http://www.jurnal.unublitar.ac.id/ \\ index.php/briliant
}

\begin{tabular}{l} 
Sejarah Artikel \\
\hline Diterima pada Januari 2021 \\
Disetuji pada Mei 2021 \\
Dipublikasikan pada Mei 2021 \\
Hal. 351-362
\end{tabular}

\begin{tabular}{l}
\hline Kata Kunci: \\
\hline Pemberdayaan Guru; Pondok \\
Pesantren; Profesionalitas Guru; \\
Pembangunan Berkelanjutan \\
\hline
\end{tabular}

\section{DOI:}

http://dx.doi.org/10.28926/brilian t.v3i4.598

di Kabupaten Batang melalui jejaring kerjasama antara pondok pesantren yang telah dibentuk pada akhir tahap pertama. Pada tahap ketiga, model yang dihasilkan dipraktekan ke pondok pesantren lain yang ada di Kabupaten Batang. Hasil penelitian menunjukan (1) Profesionalisme Guru di Pondok Pesantren dengan mampu meningkatkan kompetensinya dalam menyusun kurikulum, silabus dan RPP dengan baik, (2) Profesionalisme Guru di Pondok Pesantren dengan mampu melakukan penelitian tindakan kelas guna menunjang peningkatan kompetensi mengajarnya, (3) Profesionalisme Guru di Pondok Pesnatren dengan mampu menyusun dan menganalisis instrumen penilaian, (4) Meningkatnya kualitas mutu pondok pesantren melalui penerapan manajemen pengelolaan pondok pesantren yang baik, (5) mensosialisasikan model pemberdayaan guru ke pondok pesantren lain yang ada di Kabupaten Batang, dan (6) Mempraktikan model pemberdayaan guru yang dihasilkan ke pondok pesantren lain yang ada di Kabupaten Batang.

\section{PENDAHULUAN}

Kemajuan pesat jumlah sekolah-sekolah swasta yang bernaung di bawah pondok pesantren membawa dampak yang cukup signifikan bagi kualitas pendidikan di Indonesia. Disatu sisi, banyaknya sekolah akan semakin mempermudah akses masyarakat dalam pemenuhan kebutuhan mereka akan pendidikan. Tetapi disisi lain, jumlah sekolah yang begitu banyak dengan kualitas 
yang rendah dengan pengelolaan yang tidak baik akan menjadikan mutu pendidikan itu semakin terpuruk di mata dunia.

Pendidikan mulai kehilangan esensinya, kualitas pendidikan secara sadar tidak menjadi prioritas. Hal ini dikerenakan munculnya pergeseran makna profesionalisme yang cenderung lebih ditekankan kepada pendapatan seseorang dengan keahlian tertentu yang diperoleh melalui pendidikan dan atau pelatihan. Padahal, dalam posisi ini guru adalah pendidik yang bekerja sebagai ilmuwan, dengan jalan mana tujuan ilmuwan adalah mencari kebenaran tentang kehidupan umat manusia, sehingga lahirlah konsep pendidikan sebagai pemanusiaan manusia atau guru adalah pahlawan tanpa tanda jasa.

Dunia pendidikan dapat ditingkatkan kualitasnya dengan memanfaatkan hasil penelitian dalam bidang pendidikan dan psikologi. Tetapi kenyataan yang terjadi adalah hasil-hasil penelitian kurang dapat menjawab peningkatan kualitas pendidikan. Para peneliti (dalam penelitian non kelas) telah gagal menjawab persoalan-persoalan praktis yang dihadapi guru di kelas. Mereka lebih tertarik pada aspek publikasi ilmiah dari hasil penelitiannya, dibandingkan dengan kegiatan mengaplikasikan temuannya untuk peningkatan kualitas pendidikan. Para peneliti menyatakan bahwa apa yang dihasilkan dari kegiatan penelitian hanya menjawab persoalan-persoalan umum dalam dunia pendidikan, bukan untuk melakukan aplikasi-aplikasi tertentu dalam kelas-kelas khusus. Itulah sebabnya, persoalan teknis yang mendasar dalam dunia pendidikan masih belum terjawab.

\section{Definisi Pondok Pesantren}

Kata pondok berarti tempat yang dipakai untuk makan dan istirahat. Istilah pondok dalam konteks dunia pesantren berasal dari pengertian asrama-asrama bagi para santri. Perkataan pesantren berasal dari kata santri, yang dengan awalan pe di depan dan akhiran an berarti tempat tinggal para santri (Dhofier 1985:18). Maka pondok pesantren adalah asrama tempat tinggal para santri. Ada unsur-unsur pokok pesantren yang harus dimiliki setiap pondok pesantren. Unsur-unsur pokok pesantren, yaitu kyai. masjid, santri, pondok dan kitab Islam klasik (atau kitab kuning), adalah elemen unik yang membedakan sistem pendidikan pesantren dengan lembaga pendidikan lainnya.

Unsur-unsur pondok pesantren yaitu:

\section{a) Kyai}

Peran penting kyai dalam pendirian, pertumbuhan, perkembangan dan pengurusan sebuah pesantren berarti dia merupakan unsur yang paling esensial. Sebagai pemimpin pesantren, watak dan keberhasilan pesantren banyak bergantung pada keahlian dan kedalaman ilmu, karismatik dan wibawa, serta ketrampilan kyai. Dalam konteks ini, pribadi kyai sangat menentukan sebab dia adalah tokoh sentral dalam pesantren (Hasbullah, 1999:144).

\section{b) Masjid:}

Sangkut paut pendidikan Islam dan masjid sangat dekat dan erat dalam tradisi Islam di seluruh dunia. Dahulu, kaum muslimin selalu memanfaatkan masjid untuk tempat beribadah dan juga sebagai tempat lembaga pendidikan Islam. Sebagai pusat kehidupan rohani,sosial dan politik, dan pendidikan Islam, masjid merupakan aspek kehidupan sehari-hari yang sangat penting bagi masyarakat. Dalam rangka pesantren, masjid dianggap sebagai "tempat yang paling tepat untuk mendidik para 
santri, terutama dalam praktek sembahyang lima waktu, khutbah, dan sembahyang Jumat, dan pengajaran kitab-kitab Islam klasik." (Dhofier 1985:49) Biasanya yang pertama-tama didirikan oleh seorang kyai yang ingin mengembangkan sebuah pesantren adalah masjid.

\section{c) Santri:}

Santri merupakan unsur yang penting sekali dalam perkembangan sebuah pesantren karena langkah pertama dalam tahap-tahap membangun pesantren adalah bahwa harus ada murid yang datang untuk belajar dari seorang alim. Kalau murid itu sudah menetap di rumah seorang alim, baru seorang alim itu bisa disebut kyai dan mulai membangun fasilitas yang lebih lengkap untuk pondoknya.

\section{d) Pondok:}

Definisi singkat istilah 'pondok' adalah tempat sederhana yang merupakan tempat tinggal kyai bersama para santrinya (Hasbullah, 1999:142). Komplek sebuah pesantren memiliki gedung-gedung selain dari asrama santri dan rumah kyai, termasuk perumahan ustad, gedung madrasah, lapangan olahraga, kantin, koperasi, lahan pertanian dan/atau lahan pertenakan. Salah satu niat pondok selain dari yang dimaksudkan sebagai tempat asrama para santri adalah sebagai tempat latihan bagi santri untuk mengembangkan ketrampilan kemandiriannya agar mereka siap hidup mandiri dalam masyarakat sesudah tamat dari pesantren. Santri harus memasak sendiri, mencuci pakaian sendiri dan diberi tugas seperti memelihara lingkungan pondok.

\section{e) Kitab-Kitab Islam Klasik:}

Kitab-kitab Islam klasik dikarang para ulama terdahulu dan termasuk pelajaran mengenai macam-macam ilmu pengetahuan agam Islam dan Bahasa Arab. Dalam kalangan pesantren, kitab-kitab Islam klasik sering disebut kitab kuning oleh karena warna kertas edisi-edisi kitab kebanyakan berwarna kuning. Pada saat ini, kebanyakan pesantren telah mengambil pengajaran pengetahuan umum sebagai suatu bagian yang juga penting dalam pendidikan pesantren, namun pengajaran kitab-kitab Islam klasik masih diberi kepentingan tinggi. Melihat jumlah mata pelajaran agama kitab-kitab islam ditambah dengan ilmu-ilmu umum seperti yang bahasa Indonesia, bahasa Inggris, Matematika, Fisika, dan lainlainnya. Bisa jadi, hasil belajar yang rendah di sekolah-sekolah swasta bukan pada faktor gurunya atau siswanya, tetapi lebih cenderung kepada banyaknya materi ajar dalam kurikulum yang dijarkan. Sehingga perlu pendampingan bagi kelompokkelompok guru dalam mengelola pembelajaran, bagaimana pembelajaran dan hasil belajar menjadi lebih efektif dan mencapai sasaran melalui penelitian-penelitian.

\section{Tipologi Pondok Pesantren}

Pondok pesantren sebagai lembaga pendidikan Islam mengalami perkembangan bentuk sesuai dengan perubahan zaman, tertama sekali adanya dampak kemajuan ilmu pengetahuan dan teknologi. Perubahan bentuk pesantren bukan berarti sebagai pondok pesantren yang telah hilang kekhasannya. Dalam hal ini pondok pesantren tetap merupakan lembaga pendidikan Islam yang tumbuh dan berkembang dari masyarakat untuk masyarakat.

Secara faktual ada beberapa tipe pondok pesantren yang berkembang dalam masyarakat, yang meliputi:

\section{a) Pondok Pesantren Tradisional}


Pondok pesantren ini masih tetap mempertahankan bentuk aslinya dengan semata-mata mengajarkan kitab yang di tulis oleh ulama' pada abad ke 15 dengan menggunakan bahasa arab. Pola pengajarannya dengan menerapakan sisitem "halaqah" yang dilaksanakan di masjid atau surau. Hakekat dari sistem pengajaran halaqah adalah penghapalan yang titik akhirnya dari segi metodologi cenderung kepada terciptanya santri yang menerima dan memiliki ilmu. Kurikulumnya tergantung sepenuhnya kepada para kyai pengasuh pondoknya.

\section{b) Pondok Pesantren Modern}

Pondok pesantren ini merupakan pengembangan tipe pesantren karena orentasi belajarannya cenderung mengadopsi seluruh sistem belajar secara klasik dan meninggalkan system belajar tradisional. Penerapan sistem belajar modern ini terutama nempak pada bangunan kelas-kelas belajar baik dalam bentuk madrasa maupun sekolah. Kurikulum yang dipakai adalah kurikulum sekolah atau madrasah yang berlaku secara nasional. Perbedaannya dengan sekolah dan madrasah terletak pada porsi pendidikan agama dan bahasa Arab lebih menonjol sebagai kurikulum lokal.

\section{c) Pondok Pesantren Komprehensif}

Sistem pesantren ini disebut komprehensif merupakan sistem pendidikan dan pengajaran gabungan antara yang tradisional dan yang modern. Artinya di dalamnya diterapkan pendidikan dan pengajaran kitab kuning, namun secara reguler sistem pesekolahan terus dikembangkan. Bahkan pendidikan ketrampilan pun diaplikasikan sehingga menjadikannya berbeda dari tipologi kesatu dan kedua.

\section{Gambaran Umum Pondok Pesantren di Kabupaten Batang}

Berdasarkan data Sub Direktorat Pendidikan Diniyah dan Pondok Pesantren Kementerian Agama. Di Kabupaten Batang terdapat 31 Pondok Pesantren dengan sebaran sebagaimana berikut ini.

Table 1. Pondok Pesantren di Kabupaten Batang Tahun 2020

\begin{tabular}{|c|l|c|l|}
\hline No & Nama Pondok Pesantren & No & \multicolumn{1}{|c|}{ Nama Pondok Pesantren } \\
\hline 1 & Nurul Falah & 17 & Miftahul Ulum \\
\hline 2 & Ad Diroyah & 18 & Bardan Wassalaman \\
\hline 3 & Roudlotul Muhtadin & 19 & Khafidul Qur'an \\
\hline 4 & Nurul Huda & 20 & Darul Ulum Tragung \\
\hline 5 & Tazakka & 21 & Darul Ma' arif \\
\hline 6 & Nurul Hidayah & 22 & Tahfidlul Qur' an Al Utsmani \\
\hline 7 & Roudlotul Tholibin & 23 & Ar Roudloh \\
\hline 8 & Raudlatul Uqul & 24 & Al Hikmah Limpung \\
\hline 9 & Nashrul Huda & 25 & El-Husna \\
\hline 10 & TPI Al Hidayah & 26 & Roudlotussalam \\
\hline 11 & Al Aziziyah & 27 & An Nahdliyyah \\
\hline 12 & Darussalam Bawang & 28 & Umar Bin Khotob \\
\hline 13 & Assasul Huda 02 & 29 & Nurul Anwar \\
\hline 14 & Raudhotu Firqotinnajiyah & 30 & Darul Ulum Kemiri Timur \\
\hline 15 & Al Hikmah Sawangan & 31 & Darussalam Kemiri Barat \\
\hline 16 & Al Fatah & & \\
\hline
\end{tabular}

354 BRILIANT: Jurnal Riset dan Konseptual Volume 6 Nomor 2, Mei 2021 
Sumber: Pangkalan Data Pondok Pesantren Sub Direktorat Pendidikan Diniyah dan Pondok Pesantren Kementerian Agama, 2020

\section{Gambaran Pondok Pesantran "Bardan Wasalaman" Sebagai Pilot Project}

Pondok pesantren "Bardan Wasalaman" didirikan oleh KH. Thohirin Juhari. Jumlah keseluruhan warga pondok pesantren ini mencapai 335 (rata-rata fluktuasi) pada tahun 2019 yang terdiri dari:

a) santri aktif diniyah putra : 287 anak

b) santri aktif diniyah putri : 30 anak

c) Jumlah guru : 13 orang

d) Jumlah kepengurusan yayasan : 5 orang

\section{Konsep Pembangunan Berkelanjutan}

UNESCO (dalam Danish Ministry of Education, 2009:7) menginterpretasikan konsep pendidikan untuk pembangunan berkelanjutan menunjukkan bahwa lingkungan pendidikan dan program pembelajaran harus dapat meningkatkan kompetensi dan keterampilan masyarakat yang memungkinkan mereka dapat mengambil keputusan berdasarkan pengetahuan dan pertimbangan mengenai:

$>$ hubungan antara kebutuhan dan kepentingan saat ini dan generasi berikutnya (masa depan).

$>$ hubungan antara pelestarian dan perubahan

$>$ hubungan antara yang kaya dan miskin

$>$ hubungan antara kepentingan dan pertimbangan-pertimbangan global

Sebenarnya konsep pembangunan berkelanjutan ini sudah lama dipraktekkan dalam pendidikan pondok pesantren, dimana peserta didik tidak hanya sekadar mendapatkan ilmu-ilmu umum tetapi juga ilmu agama yang mengajarkan tentang nilai-nilai moral dan agama yang terintegrasi satu sama lainnya.

\section{Konsep Profesionalisme}

Guru memegang peranan yang sangat urgen dalam keberhasilan pendidikan yaitu untuk mencapai derajat kemanusiaan yang seutuhnya (UU No. 20 Tahun 2003). Tetapi, akhir-akhir ini pemaknaan guru telah mengalami pergeseran dari guru sebagai pendidik yang mengemban tugas/amanat yang besar dalam proses pemanusiaan manusia menjadi guru adalah tidak lebih dari sekadar pekerjaan/profesi yang tekuni seseorang untuk mencari penghasilan/pendapatan.

Kunandar (2007:45-46), menyatakan bahwa profesionalisme berasal dari kata profesi yang artinya suatu bidang pekerjaan yang ingin atau akan ditekuni oleh seseorang. Profesi juga diartikan sebagai suatu jabatan atau pekerjaan tertentu yang mensyaratkan pengetahuan dan keterampilan khusus yang diperoleh dari pendidikan akademis yang intensif. Jadi, profesi adalah suatu pekerjaan atau jabatan yang menuntut keahlian tertentu. Dimana keahlian dan kewenangan khusus dalam bidang pendidikan, pengajaran, dan pelatihan yang ditekuni untuk menjadi mata pencaharian dalam memenuhi kebutuhan hidup yang bersangkutan. Guru sebagai profesi berarti guru sebagai pekerjaan yang mensyaratkan kompetensi (keahlian dan kewenangan) dalam pendidikan dan pembelajaran agar dapat melaksanakan pekerjaan tersebut secara efektif dan efisien serta berhasil guna. Melalui penelitian ini, diharapkan guru-guru pondok 
pesantren akan memiliki kesadaran kritis tentang arti pentingnya peranan meraka dalam pembangunan manusia Indonesia seutuhnya guna mensukseskan program pembangunan berkelanjutan.

\section{Konsep Pemberdayaan}

Hakikat dari konseptualisasi pemberdayaan berpusat pada manusia dan kemanusiaan, dengan kata lain manusia dan kemanusiaan sebagai tolok ukur normatif, struktural, dan substansial. Dengan demikian konsep pemberdayaan sebagai upaya membangun eksistensi pribadi, keluarga, masyarakat, bangsa, pemerintah, negara, dan tata dunia di dalam kerangka proses aktualisasi kemanusiaan yang adil dan beradab.

Pemberdayaan bukan hanya meliputi penguatan individu anggota masyarakat, tetapi juga pranata-pranatanya. Menanamkan nilai-nilai budaya modern, seperti kerja keras, hemat, keterbukaan, dan kebertanggungjawaban adalah bagian pokok dari upaya pemberdayaan ini. Demikian pula pembaharuan institusiinstitusi sosial dan pengintegrasiannya ke dalam kegiatan pembangunan serta peranan masyarakat di dalamnya. Yang terpenting disini adalah peningkatan partisipasi masyarakat dalam proses pengambilan keputusan yang menyangkut diri dan masyarakatnya. Oleh karena itu, pemberdayaan masyarakat amat erat kaitannya dengan pemantapan, pembudayaan, pengamalan demokrasi.

Partisipasi masyarakat (guru) dalam penelitian ini, akan memberikan manfaat sebagai berikut.

a) Guru mendapatkan inovasi mengenai rencana pembangunan pendidikan di daerahnya, sehingga mampu mengetahui dampak yang akan terjadi baik yang positif maupun yang negatife, dan cara menanggulangi dampak negative yang akan dan harus dilakukan.

b) Guru ditingkatkan pengetahuannya dalam empat kompetensi mengajar: 1) pedagogik, 2) professional, 3) sosial, dan 4) personal. Sehingga mampu membentuk jejaring kerja yang solid, dimana pemerintah dapat menumbuhkan dan mengembangkan kesadaran guru akan tanggungjawabnya dalam pengelolaan pendidikan di sekolah.

c) Guru akan dapat menyiapkan diri untuk menerima manfaat yang akan dapat dinikmati dan apabila mungkin meningkatkan manfaat tersebut (dampak positif) dan ikut menekan atau menghindarkan diri terkena dampak negatife.

Dengan ikut aktifnya guru dalam pengelolaan program sejak tahap pertama penyusunan pengelolaan dan pemanfaatan program, biasanya perhatian dari instansi pemerintah yang bertanggungjawab dan pengelola pondok pesantren serta pemerkarsa program akan meningkat.

\section{METODE}

Penelitian ini dilakukan dengan menggunakan participatory action research (PAR). Action research adalah proses spiral yang meliputi (1) perencanaan tindakan yang melibatkan investigasi yang cermat; (2) pelaksanaan tindakan; dan (3) penemuan fakta-fakta tentang hasil dari tindakan, dan (3) penemuan makna baru dari pengalaman sosial.

Action research merupakan proses dimana kelompok sosial (dalam hal ini guru pondok pesantren) berusaha melakukan studi masalah mereka secara ilmiyah 
dalam rangka mengarahkan, memperbaiki, dan mengevaluasi keputusan dan tindakan yang dilakukan. Alur aktivitas program action research adalah cyclical, berupa siklus kegiatan yang berulang dan berkesinambungan. Dalam konteks program action reserach ini, siklus kegiatannya terdiri dari kegiatan (mapping), penyusunan rencana tindak (action planning), pelaksanaan rencana tindak (implementation), monitoring dan evaluasi. Hasil monitoring dan evaluasi tersebut untuk selanjutnya dipetakan kembali dan kemudian dilakukan penyusunan ulang rencana tindak (replan), implementasi, monitoring dan evaluasi, dan terus kembali berulang. Setiap selesai satu tahapan kegiatan, sesuai dengan prinsip dasar riset aksi, dilakukan kegiatan refleksi untuk mengetahui tingkat keberhasilan masingmasing tahapan.

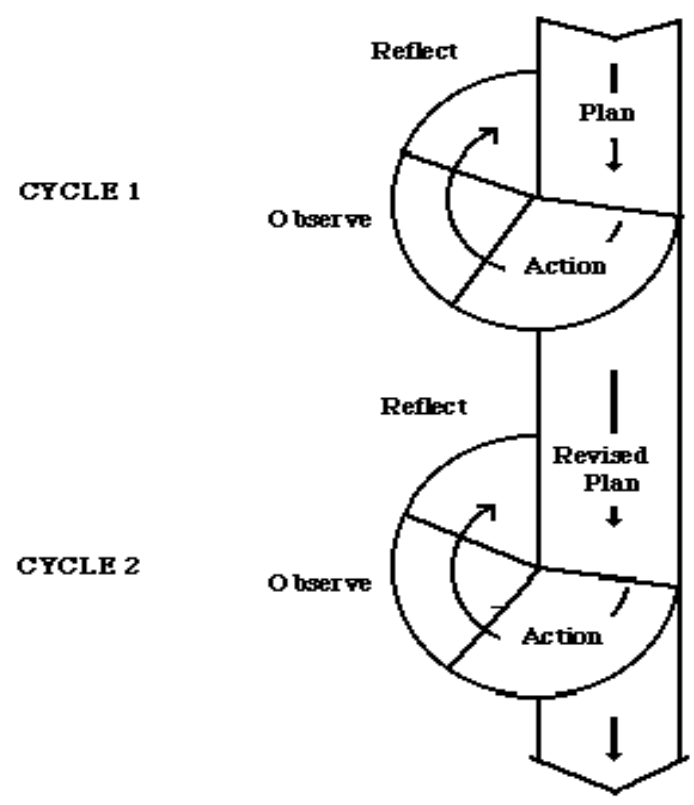

Gambar 1 Desain Action Research

(MacIsaac dalam Norton, 2009)

Oleh karena itu, program tindak lanjut dari riset ini pada dasarnya merupakan aktivitas pengulangan dari kegiatan refleksi-pemetaan ulang-penyusunan rencana tindak-pelaksanaan rencana tindak, dan monitoring dan evaluasi. Namun demikian, ada beberapa penekanan yang akan dilakukan, yakni: (1) peningkatan profesionalitas guru melalui pembelajaran berbasis hasil kajian/penelitian; (2) peningkatan kompetensi mengajar guru pondok pesantren (pedagogic, professional, social dan personal), (3) penguatan pengelolaan pondok pesantren berbasis perencanaan strategis dan (4) Penguatan jejaring kerja (networking) dan aliansi strategis antar guru pondok pesantren di Kabupaten Batang.

\section{Desain Participatory Action Research (PAR)}

Program pemberdayaan guru pondok pesantren "Bardan Wasalaman" ini hakikatnya adalah sebuah "riset aksi". Oleh karena itu, pelaksanaannya secara umum mengelaborasi konsep Participatory Action Research (PAR) dengan 
berbagai modifikasi yaitu Participatory Rural Appraisal (PRA) dan Rapid Rural Appraisal (RRA).

Sesuai dengan prinsip emancipatory research dan collaborative resources yang menjadi bagian penting dari ciri sebuah riset aksi, maka dalam pelaksanaan pemberdayaan guru pondok pesantren ini, guru dan para pengelola pondok pesantren adalah aktor utamanya (main actor). Peneliti tidak lebih dari sekedar "pendamping" yang semaksimal mungkin berusaha untuk meningkatkan kemampuan dan partisipasi stakeholders warga pondok pesantren, memetakan dan merumuskan masalah, membuat rencana tindak, melaksanakan program kegiatan, memantau dan mengevaluasi setiap proses implementasi program.

Pada setiap tahapan dan proses tersebut, peneliti juga berusaha membangun suasana dan menciptakan iklim yang kondusif, memberi berbagai masukan (input), meningkatkan kapasitas (capacity), membuka akses ke berbagai jejaring kerja (networking), peluang, dan kesempatan (opportunities) yang ada di luar komunitas warga pondok pesantren.

\section{Tahapan-Tahapan Pelaksanaan PAR dengan Pendekatan PRA dan RRA}

Adapun pelaksanaan penggunaan pendekatan PRA secara bertahap dalam penelitian ini adalah: (1) melatih guru yang bekerja pada lokasi dampingan (pondok pesantren "Bardan Wasalaman"), (2) melakukan penguatan kelembagaan dan mengarahkan tindakan produktif yang berkelanjutan; (3) mengadakan diskusi dengan melibatkan masyarakat sekitar pondok pesantren secara aktif dalam rangka meningkatkan kesadaran dan kepercayaan masyarakat agar mempunyai kekuatan untuk bertindak; (4) melakukan dialog interaktif dalam suatu forum dikusi Focus Group Discussion (FGD).

Pendekatan Rapid Rural Action (RRA) digunakan untuk mengetahui sejauhmana pengetahuan masyarakat local tentang sumberdaya yang dimiliki. Dalam pendekatan ini kegiatan yang dilakukan sudah memunculkan alternative yang lebih baik tentang pengelolaan pondok pesantren dan pengelolaan pembelajaran yang professional berbasis hasil kajian/penelitian. Hal ini mengantarkan pada apa yang disebut sebagai pengetahuan teknik setempat atau pengetahuan ekologi setempat, suatu penerimaan yang mempunyai banyak manfaat untuk menyelesaikan masalah.

\section{Strategi Pelaksanaan}

Strategi yang digunakan dalam program ini adalah

1) Memperkuat posisi (positioning) warga pondok pesantren yang mapan dan professional dalam pembangunan pendidikan yang berkualitas dan berkelanjutan.

2) Mendorong peran aktif guru dalam pengelolaan pembelajaran yang berbasis pada hasil kajian/penelitian dalam rangka meningkatkan kompetensi/sumber daya lokal

3) Mengembangkan program yang bersifat strategis secara lokal sehingga terasa manfaatnya secara langsung bagi pengembangan pondok pesantren.

4) Membangun media informasi dalam bidang pengembangan dan pemberdayaan guru pondok pesantren di Kabupaten Batang dalam rangka mengimbangi dinamika masyarakat yang mengalami kemajuan pesat dalam era globalisasi

358 BRILIANT: Jurnal Riset dan Konseptual Volume 6 Nomor 2, Mei 2021 
5) Menggalang kerjasama dengan seluruh pondok pesantren yang ada di Kabupaten Batang dan berbagai pihak yang mendukung pengembangan dan pemberdayaan guru professional.

\section{HASIL DAN PEMBAHASAN}

Hasil pelaksanaan penelitian Tahap Awal, dilakasanakan Focus Group Discussion (FGD) untuk mengetahui dan memetakan berbagai permasalahanpermasalahan yang dihadapi Guru Pondok Pesantren sehingga dapat dilakukan evaluasi dan menerapkan tindakan yang tepat untuk memperbaiki. Hasil FGD diperoleh penerapan tindakan melalui Desain Participatory Action Research (PAR). Siklus kegiatannya terdiri dari kegiatan (mapping), penyusunan rencana tindak (action planning), pelaksanaan rencana tindak (implementation), monitoring dan evaluasi. Hasil monitoring dan evaluasi tersebut untuk selanjutnya dipetakan kembali dan kemudian dilakukan penyusunan ulang rencana tindak (replan), implementasi, monitoring dan evaluasi, dan terus kembali berulang. Setiap selesai satu tahapan kegiatan, sesuai dengan prinsip dasar riset aksi, dilakukan kegiatan refleksi untuk mengetahui tingkat keberhasilan masing-masing tahapan.

Tahap Kedua, pemberdayaan Guru melalui pelaksanaan tindakan dengan memberikan pengetahuan dan pemahaman kepada para Guru Pondok Pesantren Bardan Wasalaman dari proses hingga hasil pembelajaran. Pemberdayaan bertujuan menjadikan masyarakat mandiri dan mampu mengatasi permasalahannya sendiri, bukan menjadikan masyarakat tergantung pada pihak luar (Muslim, 2017:81). Pendidikan Pesantren merupakan sebagai wadah dalam melakukan proses pendidikan masyarakat sekaligus modal sosial yang terus diberikan penguatan dan penghargaan untuk terus melakukan tranformasi manusia seutuhnya (Aulia dkk, 2018:74). Proses pengembangan dunia pesantren harus didukung oleh Pemerintah secara serius sebagai proses pembangunan manusia seutuhnya. Meningkatkan dan mengembangkan peran pesantren dalam proses pembangunan di era otonomi daerah merupakan langkah strategis dalam upaya mewujudkan tujuan pembangunan Nasional terutama sektor pendidikan (Syafe'i, 2017:64). Dalam mewujudkan pendidikan pesantren yang berkualitas sehingga dilakukan upaya pemberian tindakan kepada para guru pondok pesantren melalui (1) pelatihan penyusunan kurikulum, silabus dan RPP, (2) pelatihan penelitian tindakan kelas, dan (3) pelatihan penyusunan dan analisis instrument penilaian. Menurut Mulyasa, (2005:13-14) untuk mengukur kualitas guru setidaknya dapat ditinjau dari dua aspek yaitu dari aspek proses dan aspek hasil pembelajaran.

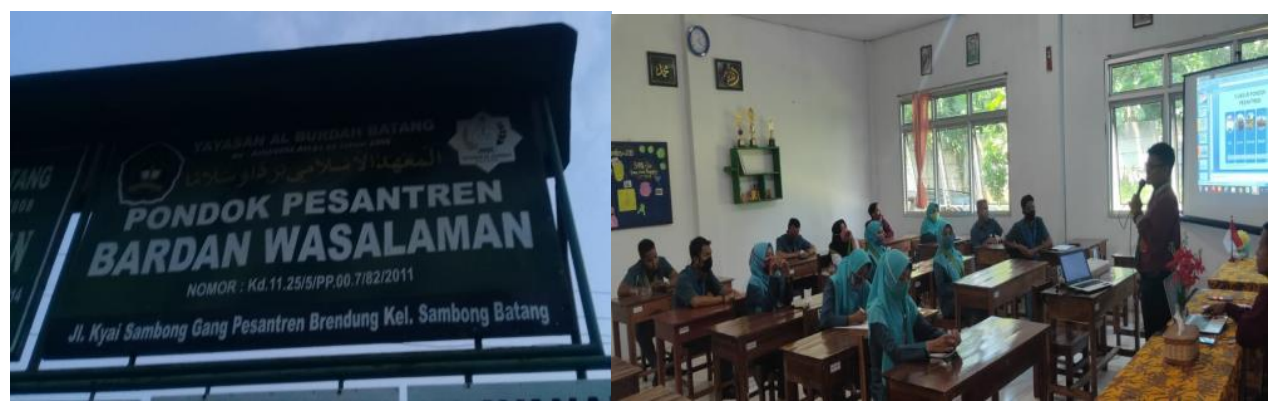

Gambar 2. Kegiatan Pelatihan Guru di Pondok Pesntren Bardan Wasalaman 
Pelatihan-pelatihan yang dilaksanakan di Pondok Pesantren Bardan Wasalaman diikuti seluruh Guru dengan jumlah seluruhnya 13 Guru. Pertama, Pelatihan penyusunan kurikulum, silabus dan RPP sangat perlu diberikan kepada Guru agar mampu melaksanakan penyusunan kurikulum, silabus dan RPP dengan benar sesuai standar yang diterapkan Pemerintah dan kebutuhan sekolah. Menurut Abdullah, (1992:78) Guru memegang peranan yang cukup penting baik dalam perencanaan maupun pelaksanaan kurikulum. Pemahaman ini akan sangat menunjang dalam proses pelaksanaan pembelajaran lebih baik. Kedua, Pelatihan penelitian tindakan kelas akan dapat meningkatkan profesionalitas guru sebab guru mampu memecahkan permasalahan-permasalahan yang dihadap dalam proses pembelajaran di kelas sehingga dengan penelitian tindakan kelas akan mampu menemukan solusi-solusi dari berbagai permasalahan yang ada di kelas. Selain itu, melalui penelitian tindakan kelas guru dapat menggunakan untuk menunjang dalam memenuhi kenaikan pangkat/golongan dan sertifikasi guru sehingga mampu menjadi guru yang profesional. Ketiga, pelatihan penyusunan dan analisis instrument penilaian memberikan pemahaman para Guru Pondok Pesantren Bardan Wasalaman dalam menyusun dan melakukan penilaian hasil belajar dengan baik.

Tahap Ketiga (Terakhir), setelah semua kegiatan pada tahap dua dilaksanakan kemudian dilakukan monitoring, evaluasi dan pendampingan agar program kegiatan yang telah dilaksanakan dapat terus berjalan dengan baik. Monitorin dilakukan untuk memastikan bahwa guru Pondok Pesantren Bardan Wasalaman yang telah mengikuti pelatihan mampu menangkap kegiatan pelatihan dengan baik. Menurut Rahmat dan Minawarti (2020:68) Proses Evaluasi dalam riset aksi partisipatif menekankan pada penjabaran proses dari aksi pemberdayaan yang dilakukan sehingga dapat mempertimbangkan kekurangan, kelebihan, kelemahan dan kekuatan dari aksi pemberdayaan yang telah dilakukan. Berdasarkan pendapat tersebut evaluasi dilakukan untuk memperbaiki yang dirasa masih perlu dilakukan dalam proses kegiatan pelatihan Guru Pondok Pesantren. Pendampingan dilakukan untuk memastikan Guru Pondok Pesntren Bardan Wasalaman mempu menerapkan hasil kegiatan pelatihan dalam proses dan hasil pembelajaran yang dilakukannya. Pendidikan Pesantren merupakan sebagai wadah dalam melakukan proses pendidikan masyarakat sekaligus modal sosial yang terus diberikan penguatan dan penghargaan untuk terus melakukan tranformasi manusia seutuhnya (Aulia dkk, 2018:74). Proses pengembangan dunia pesantren harus didukung oleh Pemerintah secara serius sebagai proses pembangunan manusia seutuhnya. Meningkatkan dan mengembangkan peran pesantren dalam proses pembangunan di era otonomi daerah merupakan langkah strategis dalam upaya mewujudkan tujuan pembangunan Nasional terutama sektor pendidikan (Syafe'i, 2017:64). Strategi pembangunan pendidikan yang efektif mutlak diperlukan yaitu strategi pembangunan yang memberdayakan, memberikan kepercayaan yang lebih luas dan mengembalikan urusan pengelolaan pendidikan kepada sekolah (Manaf, 2016:108). Sebenarnya konsep pembangunan berkelanjutan ini sudah lama dipraktekkan dalam pendidikan pondok pesantren, dimana peserta didik tidak hanya sekadar mendapatkan ilmu-ilmu umum tetapi juga ilmu agama yang mengajarkan tentang nilai-nilai moral dan agama yang terintegrasi satu sama lainnya.

360 BRILIANT: Jurnal Riset dan Konseptual Volume 6 Nomor 2, Mei 2021 
Hasil penelitian menunjukan (1) Profesionalisme Guru di Pondok Pesantren mampu meningkatkan kompetensinya dalam menyusun kurikulum, silabus dan RPP dengan baik, (2) Profesionalisme Guru di Pondok Pesantren dengan mampu melakukan penelitian tindakan kelas guna menunjang peningkatan kompetensi mengajarnya, (3) Profesionalisme Guru di Pondok Pesantren dengan mampu menyusun dan menganalisis instrumen penilaian, (4) Meningkatnya kualitas mutu pondok pesantren melalui penerapan manajemen pengelolaan pondok pesantren yang baik dalam pembangunan berkelanjutan, (5) mensosialisasikan model pemberdayaan guru ke pondok pesantren lain yang ada di Kabupaten Batang, dan (6) Mempraktikan model pemberdayaan guru yang dihasilkan ke pondok pesantren lain yang ada di Kabupaten Batang.

\section{KESIMPULAN}

Penelitian ini menyimpulkan (1) Profesionalisme Guru di Pondok Pesantren mampu meningkatkan kompetensinya dalam menyusun kurikulum, silabus dan RPP dengan baik, (2) Profesionalisme Guru di Pondok Pesantren dengan mampu melakukan penelitian tindakan kelas guna menunjang peningkatan kompetensi mengajarnya, (3) Profesionalisme Guru di Pondok Pesantren dengan mampu menyusun dan menganalisis instrumen penilaian, (4) Meningkatnya kualitas mutu pondok pesantren melalui penerapan manajemen pengelolaan pondok pesantren yang baik dalam pembangunan berkelanjutan, (5) mensosialisasikan model pemberdayaan guru ke pondok pesantren lain yang ada di Kabupaten Batang, dan (6) Mempraktikan model pemberdayaan guru yang dihasilkan ke pondok pesantren lain yang ada di Kabupaten Batang.

\section{SARAN}

Pelatihan-pelatihan mengenai penyusunan kurikulum, silabus, RPP, penelitian tindakan kelas dan istrumen penilaian mampu meningkatkan kompetensi mengajar dan meningkatkan profesionalisme Guru Pondok Pesantren sehingga perlu dilakukan kegiatan pelatihan-pelatihan secara berkala kedepannya. Pengelola pondok pesantren perlu memahami manajemen pengelolaan pondok pesantren dengan baik agar berbagai kekurangan manajemen segera diperbaiki agar pondok pesantren dapat selalu mendukung dalam proses pembangunan berkelanjutan.

\section{DAFTAR RUJUKAN}

Muslim, Aziz. (2017). Analisis Program Nasional Pemberdayaan Masyarakat dalam Membangun Kemandirian Masyarakat Miskin. Jurnal Penyuluhan Vol. 13 No. 1: (79 - 87).

Aulia, Rihlah Nur., Narulita, Sari., Firdaus, Moh., Mardhiah, Izzatul. 2018. Pengelolaan Pendidikan Lingkungan Berbasis Pesantren. Jurnal Penddikan Lingkungan dan Pembangunan Berkelanjutan Vol. 19 No. 1: $(73-88)$.

Syafe'i, Imam. 2017. Pondok Pesantren: Lembaga Pendidikan Pembentuk Karakter. Jurnal Pendidikan Islam Vol. 8 No. 1: $(61$ - 82)

Mulyasa. (2005). Menjadi Guru, Menciptakan Pelajaran Kreatif dan Menyenangkan, Bandung: Remaja Rosdakarya.

Abdullah, Nasyih Ulwan. (1992). Tarbiyatul Aulad fil Islam, Terjemahan Halilulah 
Ahmas, Bandung, Remaja Rosdakarya.

Rahmat, Abdul \& Mirnawati, Mira. (2020). Model Participation Action Research Dalam Pemberdayaan Masyarakat. Aksara : Jurnal Ilmiah Pendidikan Nonformal Vol. 06 No. $01(62-71)$.

Manaf, Abdul. (2016). Hubungan Pemberdayaan Guru dengan Profesionalisme Guru dan Mutu Pendidikan. Jurnal Penelitian Manajemen Pendidikan Vol. 10 No. 2: $(108-118)$. 